\title{
Perbedaan Mekanisme Koping antara Mahasiswa Laki-Laki dan Perempuan dalam Menghadapi Ujian Semester pada Fakultas Tarbiyah IAIN Raden Intan Lampung
}

\author{
Andi Thahir \\ Dosen Fakultas Tarbiyah dan Keguruan, IAIN Raden Intan Lampung \\ Diterima: April 2014. Disetujui: Mei 2014. Dipublikasikan: Juni 2014
}

\begin{abstract}
Abstrak: Mahasiswa dalam peraturan pemerintah RI No.30 tahun 1990 adalah peserta didik yang terdaftar dan belajar di perguruan tinggi tertentu. Mahasiswa merupakan suatu kelompok dalam masyarakat yang memperoleh statusnya karena ikatan dengan perguruan tinggi. Pada variabel mahasiswa laki-laki diperoleh sebanyak 160 responden (64\%) mempunyai mekanisme koping konstruktif dan sebanyak 90 responden (36\%) mempunyai mekanisme koping destruktif. Pada variabel perempuan diperoleh sebanyak 200 responden (80\%) mempunyai mekanisme koping konstruktif dan sebanyak 50 responden (20\%) memiliki mekanisme koping destruktif. Hasil analisis Bivariat menggunakan Chi Square diperoleh $\chi^{2}$ hitung $=0,893$ dan $\chi^{2}$ tabel $=3,488$. Hal ini berarti tidak ada perbedaan mekanisme koping antara mahasiswa laki-laki dan perempuan dalam menghadapi ujian semester ganjil tahun ajaran 2010/2011 di Fakultas Tarbiyah IAIN Raden Intan Lampung
\end{abstract}

Kata Kunci : mekanisme koping

\section{Pendahuluan}

Mahasiswa dalam peraturan pemerintah RI No.30 tahun 1990 adalah peserta didik yang terdaftar dan belajar di perguruan tinggi tertentu. Mahasiswa merupakan suatu kelompok dalam masyarakat yang memperoleh statusnya karena ikatan dengan perguruan tinggi. Mahasiswa juga merupakan calon intelektual atau cendekiawan muda dalam suatu lapisan masyarakat yang sering kali syarat dengan berbagai predikat. Dari pendapat di atas bisa dijelaskan bahwa mahasiswa adalah status yang disandang oleh seseorang karena hubungannya dengan perguruan tinggi yang diharapkan menjadi calon-calon intelektual.

Demikian banyak predikat yang disandangnya, maka dalam kesehariannya mahasiswa dapat juga mengalami stress. Stress yang sering dihadapi oleh mahasiswa salah satunya adalah stress dalam menghadapi ujian semester. Stress merupakan kebutuhan nonspesifik yang mengakibatkan seseorang berespon dan berbuat sesuatu (Kozier, 1999). Respon yang ditimbulkan saat terjadi stress akan mengakibatkan suatu perubahan pada individu. Stressor bisa didapat dimana saja dan kapan saja, walaupun individu tidak berada di tempat stressor berada. Untuk menanggulangi stress dalam menghadapi ujian tengah semester, mahasiswa sebagai individu mempunyai mekanisme koping yang dianggap paling baik, meskipun tidak selalu mekanisme koping yang digunakan menguntungkan. Seperti prilaku mondar- mandir sehingga waktu belajar habis, mencari jalan pintas contohnya mencontek.

Untuk menghadapi stressor, setiap individu memiliki mekanisme koping yang khas. Mekanisme koping merupakan proses mengelola tuntutan (internal atau eksternal) yang ditaksir sebagai beban karena diluar tuntutan diri individu (Yusuf, 2004). Berbagai mekanisme koping yang digunakan dapat bersifat konstruktif ataupun destruktif. Mekanisme koping konstruktif sangat bermanfaat bagi individu karena dapat mengembangkan potensi serta mengasah keahlian diri bila berhadapan dengan suatu masalah. Sedangkan mekanisme koping destruktif menyebabkan kemunduran bagi individu dan sangat merugikan karena hal itu tidak akan menyelesaikan masalah dengan tuntas. Oleh karena itu sangat penting bagi mahasiswa untuk mengetahui mekanisme koping yang biasa digunakan, hal ini berguna agar mahasiswa dapat memperbaiki mekanisme koping destruktif yang secara sadar ataupun tidak telah membawanya pada kemunduran baik fisik maupun psikis. Keahlian koping individu dipengaruhi oleh faktor-faktor fisiologi, psikologis, sosial dan kultural. 
Hal ini menyebabkan perbedaan mekanisme koping pada masing-masing individu. Perbedaan mekanisme koping yang digunakan pada laki-laki dengan perempuan disebabkan oleh faktor fisiologis, dimana kecenderungan perempuan lebih menggunakan mekanisme koping yang berfokus pada emosi sedangkan laki-laki lebih menggunakan mekanisme koping fokus problem solving (Elizabeth, 1999). Dalam koping yang berfokus pada problem solving tentunya akan menghasilkan mekanisme koping konstruktif dan mekanisme koping yang berfokus pada emosi akan lebih destruktif karena akan mengedepankan perasaan dari pada pemecahan masalah.

Berdasarkan survei awal yang dilakukan peneliti di Fakultas Tarbiyah IAIN Raden Intan Lampung, tanggal 12-18 November 2011 dari 20 mahasiswa yang ditanya, serta pengalaman peneliti sendiri didapatkan data-data mekanisme koping konstruktif laki-laki sebesar $80 \%$ dan destruktif sebesar 20\%, sedangkan mekanisme koping konstruktif perempuan sebesar $60 \%$ dan destruktif sebesar 40\%. Mekanisme koping konstruktif berupa: melakukan aktivitas lain selain belajar untuk sejenak seperti menonton TV dan membaca novel, belajar kelompok, menganggap ujian sebagai tantangan yang harus dihadapi, membuat jadwal belajar, bertanya pada dosen tentang pelajaran yang akan diujikan, menandai kalender untuk mengingat saat ujian, melakukan olah raga, menikmati musik. Mekanisme koping destruktif berupa: prilaku mondar-mandir sehingga waktu belajar habis, menyibukkan diri dengan aktivitas ekstrakulikuler yang berlebih (tanpa memperhatiakan waktu, kesehatan), memberikan diri standart yang terlalu rendah contohnya mendapat nilai berapa saja yang penting lulus ujian, mencari jalan pintas contohnya mencontek, makan minum secara berlebihan dari biasanya, mengkonsumsi obat-obatan (contohnya obat sakit kepala, obat tidur) dan merokok. Serta dari survei peneliti dibagian akademik, menunjukkan bahwa indek prestasi laki-laki lebih besar dibanding perempuan. Begitu pula prilaku yang nampak dalam menghadapi ujian laki- laki nampak tenang dalam mengerjakan soal ujian, sedangkan perempuan terlihat sibuk menoleh kiri kanan mencari contekan dari teman sebelahnya. Hal ini didukung oleh teori (Elizabeth, 1999) bahwa mekanisme koping laki-laki berfokus pada problem solving sedangkan perempuan menggunakan mekanisme koping yang berfokus pada emosi.

Stress merupakan suatu keadaan yang membutuhkan aksi dan respon dari seseorang untuk memenuhi kebutuhan yang nonspesifik (Kozier, 1999). Stress sebagai suatu kondisi disebabkan oleh transaksi antara individu dengan lingkungan yang menimbulkan persepsi jarak antara tuntutan dengan sumber-sumber daya sistem biologis, psikologis dan sosial dari seseorang (Smet, 1994).

Setiap individu dapat mengalami stress kapan saja dan dimana saja. Termasuk juga kalangan mahasiswa yang sering kali menjadi stress bila akan menghadapi ujian tengah semester. Hal ini memicu suatu perubahan akibat stress disebut dengan stressor (Taylor \& C. Le Mone.P, 1997). Ujian merupakan stressor yang harus selalu dihadapi mahasiswa dari waktu ke waktu selama pembelajarannya. Individu akan memberi reaksi yang berbeda-beda terhadap stressor yang sama. Tumbuhnya kesadaran terhadap stress merupakan proses yang komplek dan dinamis, yang sesuai dengan pendekatan biopsikososial terhadap kehidupan manusia.

Manusia merespon peristiwa stress dengan fisik maupun psikis untuk mempersiapkan dirinya apakah melawan/mengatasi atau menghindari atau melarikan diri dari stress fight or flight respon. Ketika individu mempersiapkan adanya ancaman, maka tubuhnya secara cepat mereaksinya melalui sistem syaraf simpatik dan endokrin. Respon atau reaksi tubuh itu memobilisasi organisme untuk menyerang atau menghindari ancaman tersebut.

Manifestasi fisiologi stress terjadi dari pengalaman individu. Tergantung cara individu melihat peristiwa yang menjadi penyebab stress dan strategi koping efektif yang dapat digunakan. Manifestasi fisiologi seperti pupil melebar, berkeringat, detak jantung meningkat, kulit pucat, tekanan darah naik, pernapasan cepat, mulut kering peristaltik usus menurun, gula darah meningkat, penurunan fungsi fisiologi dan kehilangan tonus otot. Sementara manifestasi 
psikologi stress termasuk ansietas, marah, prilaku kognitif, respon verbal dan motorik serta mekanisme pertahanan ego (Kozier, 1999).

Ada tiga aspek respon sosial individu terhadap stress dan penyakit. Aspek pertama "mencari arti" dimana orang akan mencari informasi mengenai masalahnya hal ini diperlukan untuk merencanakan strategi koping yang akan digunakan. Aspek kedua yaitu sifat sosial, dimana seseorang mencoba mengidentifikasikan faktor-faktor yang dapat membantu dalam situasi stress. Seseorang melihat masalahnya sebagai akibat dari kelalaian dirinya, serta menyalahkan diri sendiri, pasif serta prilaku menarik diri. Aspek sosial yang ketiga yaitu perbandingan sosial, dimana seseorang membandingkan masalahnya dengan masalah orang lain yang sama (Stuart \& Laraia, 1998)

Sress dapat memberikan pengaruh positif maupun negatif terhadap individu. Pengaruh positif, yaitu mendorong individu untuk melakukan sesuatu membangkitkan kesadaran, dan menghasilkan pengalaman baru. Sedangkan pengaruh negatif yaitu menimbulkan perasaanperasaan tidak percaya diri, penolakan, marah atau depresi dan memicu berjangkitnya penyakit seperti sakit kepala, sakit perut, insomnia, tekanan darah tinggi atau stroke (Yusuf, 2004). Pada mahasiswa stressor ujian diharapkan menjadi hal yang positif, karena ujian akan memicu seseorang untuk meningkatkan pengetahuannya sehingga kemampuan dan daya pikir yang dimiliki akan meningkat.

Mekanisme koping didefinisikan sebagai segala upaya yang digunakan untuk mengelola stress (Stuart \& Laraia, 1998). Koping berkaitan dengan prilaku atau keterampilan yang digunakan individu untuk menyesuaikan diri dengan kejadian atau situasi yang tidak biasa.

Mekanisme koping terdiri dari tiga tipe yaitu:

1. Mekanisme koping fokus problem untuk mengurangi stressor individu akan mengatasi dengan mempelajari cara-cara atau keterampilan yang baru. Individu akan cenderung menggunakan strategi ini bila dirinya yakin akan mengubah situasi yang menjadi stress. Contohnya, negosiasi, konfrontasi, mencari nasehat.

2. Mekanisme koping fokus emosi, digunakan untuk mengatur respon emosional terhadap stress pengaturan ini melalui prilaku individu seperti, penggunaan alcohol, meniadakan fakta-fakta yang tidak menyenangkan, supresi, proyeksi, denial.

3. Mekanisme koping fokus kognitif yaitu berusaha mengontrol problem dan berusaha menetralisirnya, seperti dengan melakukan perbandingan positif, substitusi reward dan mengurangi obyek yang diinginkan (Stuart \& Laraia, 1998).

Mekanisme koping juga diklasifikasikan menjadi dua kategori yaitu tindakan langsung dan paliatif. Tindakan langsung termasuk "serangan" terhadap stimulus yang mengakibatkan stress itu sendiri. Contohnya koping langsung stress timbul karena ujian yang sudah dekat adalah dengan mengulang kembali pelajaran dengan baik atau tidak jadi mengikuti ujian. Tindakan itu secara langsung mencoba mengurangi atau menghilangkan stress. Sebaliknya, tindakan paliatif memodifikasi respon internal individu terhadap stimulus. Ancaman masih tetap ada tetapi individu dapat mengatasinya dengan baik. Contohnya dengan minum-minuman atau melibatkan diri dengan latihan relaksasi (Niven, 2000).

Prilaku mekanisme koping untuk menurunkan stress antara lain dengan menangis, tertawa, tidur, mengeluarkan makian, melakukan aktivitas fisik dan olah raga, makan, merokok dan minum-minuman keras, menarik diri, membatasi hubungan dengan orang yang mempunyai masalah yang sama. Apabila seseorang sedang dilanda masalah yang berat maka mekanisme koping yang digunakan akan berbeda dengan orang yang masalahnya ringan. Mekanisme koping yang digunakan ini tergantung tingkat ansietas, ancaman dan perlibatan mekanisme koping yang lebih komplek (Taylor \& C. Le Mone.P, 1997). Koping terhadap stress tergantung pada pengalaman seseorang dengan stressor yang serupa dan persepsi terhadap stressor itu 
sendiri. Tentunya koping yang digunakan juga berbeda-beda sesuai dengan individu yang mengalaminya (Kozier, 1999).

Mekanisme koping dapat berupa koping yang konstruktif atau destruktif. Koping konstruktif akan muncul jika individu melihat kecemasan atau stressor yang dihadapinya sebagai tanda peringatan sehingga individu tersebut menghadapinya sebagai kesempatan untuk memecahkan masalah Umumnya, jika sekali koping konstruktif ini digunakan dan berhasil maka koping ini akan terus digunakan untuk menghadapi stressor yang datang berikutnya. Koping destruktif merupakan mekanisme individu untuk menghindari stressor tanpa adanya penyelesaian masalah (Stuart \& Laraia, 1998). Mekanisme koping konstruktif diartikan sebagai upaya-upaya untuk menghadapi stress secara sehat. Koping konstruktif memiliki ciri-ciri sebagai berikut: menghadapi masalah secara langsung, mengevaluasi alternatif secara rasional dalam upaya memecahkan masalah, menilai atau mempersepsikan situasi stress didasarkan kepada pertimbangan yang rasional, mengendalikan diri (self control) dalam mengatasi masalah yang dihadapi.

Mekanisme koping destruktif seperti melarikan diri dari kenyataan atau situasi stress yang bentuknya seperti sikap apatis, kehilangan semangat atau perasaan tak berdaya, minumminuman keras atau mengkonsumsi obat-obatan terlarang, mencela diri sendiri atau menilai negatif diri sendiri, agresif yaitu berbagai prilaku yang ditujukan untuk menyakiti orang lain, memanjakan diri sendiri dengan berprilaku berlebihan seperti makan yang enak-enak, merokok minum-minuman keras, menghabiskan uang untuk berbelanja, serta mekanisme pertahanan diri yang bentuknya seperti menolak kenyataan dengan cara melindungi diri dari suatu kenyataan yang tidak menyenangkan dengan cara seperti seorang perokok mengatakan bahwa rokok merusak kesehatan hanya teori belaka, berfantasi, intelektualisasi (Yusuf, 2004).

Pada penelitian ini, peneliti mengambil mekanisme koping konstruktif dan mekanisme koping destruktif (Yusuf, 2004), sebagai panduan dalam pembuatan kuesioner penelitian.

Mekanisme koping pada mahasiswa laki-laki dan perempuan memiliki perbedaan, menurut White E, 1999 perbedaan mekanisme koping yang digunakan pada laki-laki dan perempuan disebabkan oleh faktor fisiologis, dimana kecenderungan perempuan lebih menggunakan mekanisme koping fokus emosi, contoh mekanisme koping fokus emosi: sebuah ujian tidak selalu dapat dihindarkan tetapi ancaman dari ujian itu dapat dikurangi dengan minum-minuman, menyibukkan diri dengan aktivitas ekstrakulikuler yang berlebihan, mencoba mengurangi ketegangan dengan makan lebih dari biasanya atau menahan rasa lapar, merokok, serta mempersiapkan diri untuk kemungkinan yang lebih buruk seperti mendapat nilai berapa saja yang penting lulus ujian, sedangkan laki-laki lebih menggunakan mekanisme koping fokus problem solving. Mekanisme koping fokus problem solving contohnya mengambil beberapa tindakan yang positif seperti mempelajari kembali pelajaran sedikit demi sedikit, belajar kelompok, mempertimbangkan beberapa alternatif untuk mengatasi masalah seperti membuat prioritas kegiatan yang akan dilakukan menjelang ujian, menandai kalender untuk mengingat saat ujian, membuat jadwal belajar serta menyelesaikan masalah satu demi satu (Elizabeth, 1999). Perempuan relatif cenderung menggunakan strategi koping dukungan sosial, fokus emosi serta pencegahan sedangkan laki-laki cenderung menghilangkan stress dengan menggunakan aktivitas, obat-obatan atau alkohol (Lengua \& Stomrmshak, 2000).

\section{Metode Penelitian}

Dalam penelitian ini, peneliti menggunakan desain deskriptif perbandingan karena sampel yang digunakan terdiri dari 2 kelompok yaitu kelompok mahasiswa laki-laki dan kelompok mahasiswa perempuan. Penelitian dilakukan dengan prosedur pengumpulan data 
dari responden menggunakan pertanyaan terstruktur dalam bentuk kuesioner penelitian. Penelitian ini dilaksanakan Ingin mengetahui perbedaan mekanisme koping antara mahasiswa laki-laki dan perempuan dalam menghadapi ujian semester ganjil tahun ajaran 2010/2011 di Fakultas Tarbiyah IAIN Raden Intan Lampung.

Dalam penelitian ini, peneliti menggunakan desain deskriptif perbandingan karena sampel yang digunakan terdiri dari 2 kelompok yaitu kelompok mahasiswa laki-laki dan kelompok mahasiswa perempuan. Penelitian dilakukan dengan prosedur pengumpulan data dari responden menggunakan pertanyaan terstruktur dalam bentuk kuesioner penelitian.

\section{Hasil dan Pembahasan}

Penelitian ini dilaksanakan pada mahasiswa Fakultas Tarbiyah IAIN Raden Intan Lampung dengan jumlah responden 500 orang. Proses pengumpulan data dilakukan dengan membagikan kuesioner pada responden yang telah ditentukan sebelumnya. Adapun hasil penelitian ini disajikan dalam bentuk tabel.

Penelitian ini menggunakan analisis univariate yang bertujuan untuk melihat distribusi frekuensi karekteristik responden, variabel independent yaitu mahasiswa laki- laki dan perempuan dan variabel dependen yaitu mekanisme koping. Responden terdiri dari 500 responden, karakteristik responden di destkipsikan dalam tabel 1 berikut:

Tabel 1. Distribusi Frekuensi Berdasarkan Karakteristik Responden

\begin{tabular}{llll}
\hline No & Karakteristik & Jumlah & Persentase \\
\hline \multirow{3}{*}{1} & Jenis kelamin & & \\
\cline { 2 - 4 } & Laki-laki & 250 & $50 \%$ \\
\cline { 2 - 4 } & Perempuan & 250 & $50 \%$ \\
\hline \multirow{3}{*}{2} & Semester & & \\
\cline { 2 - 4 } 2 & I & 70 & $14 \%$ \\
\cline { 2 - 4 } & III & 240 & $48 \%$ \\
\cline { 2 - 4 } & V & 160 & $32 \%$ \\
\cline { 2 - 4 } & VII & 30 & $6 \%$ \\
\hline
\end{tabular}

Mekanisme Koping Mahasiswa Laki-laki Dari 250 responden penelitian, variable dependent yaitu mahasiswa laki-laki di deskripsikan dalam tabel 2 berikut:

Tabel 2. Distribusi Frekuensi Mekanisme Koping Responden Laki- laki

\begin{tabular}{clll}
\hline No & Mekanisme & Frekuensi & Persentase \\
\hline 1. & Konstruktif & 160 & $64 \%$ \\
\hline 2. & Destruktif & 90 & $36 \%$ \\
\hline Jumlah & & 250 & $100 \%$ \\
\hline
\end{tabular}

Dari tabel diatas terlihat responden laki-laki yang memiliki mekanisme koping konstruktif 160 orang (64\%), sedangkan responden yang memiliki mekanisme koping destruktif sebanyak 90 orang (36\%). Mekanisme Koping Mahasiswa Perempuan Dari 250 responden penelitian, variable dependen yaitu mahasiswa perempuan dideskripsikan dalam tabel 3 berikut:

Tabel 3. Distribusi Frekuensi Mekanisme Koping Responden

\begin{tabular}{clll}
\hline No & Mekanisme & Frekuensi & Persentase \\
\hline 1. & Konstruktif & 200 & $80 \%$ \\
\hline 2. & Destruktif & 50 & $20 \%$ \\
\hline
\end{tabular}


Dari tabel diatas terlihat responden laki-laki sebanyak 250 orang (50\%) dan responden perempuan sebanyak 250 orang (50\%). Pada semester responden terlihat semester I sebanyak 70 orang $(14 \%)$, semester III sebanyak 240 orang (48\%), semester V sebanyak 160 orang (32\%) dan semester VII sebaanyak 30 orang (6\%).

Dari tabel diatas terlihat responden perempuan yang memiliki mekanisme koping konstruktif 200 orang (80\%), sedangkan responden yang memiliki mekanisme koping destruktif sebanyak 50 orang (20\%).

Analisis bivariate yang dilakukan dimaksudkan untuk membuat suatu kesimpulan dengan melakukan suatu pembuktian secara statistik mengenai hubungan antara variabel yang diteliti dengan melakukan uji hipotesis yang telah ditetapkan dengan suatu statistik nonparametrik dengan Chi Square karena data yang diperoleh berupa kategori dengan tingkat kemaknaan $\chi^{2}$

$=0,05$. Hasil analisa yang disajikan adalah perbedaan mekanisme koping antara mahasiswa laki-laki dan perempuan dalam menghadapi ujian semester ganjil tahun ajaran 2010/2011 di Fakultas Tarbiyah IAIN Raden Intan Lampung yang terlihat pada tabel 4 berikut:

Tabel 4. Perbedaan Mekanisme Koping

Antara Mahasiswa Laki-laki dan Perempuan dalam Menghadapi Ujian Semester

\begin{tabular}{|c|c|c|c|c|c|c|c|c|}
\hline \multirow{2}{*}{ Jenis Kelamin } & \multicolumn{4}{|c|}{ Mekanisme Koping } & \multirow{2}{*}{\multicolumn{2}{|c|}{ Total }} & \multirow{3}{*}{$\begin{array}{c}\text { OR } \\
95 \% \mathrm{CI} \\
\end{array}$} & \multirow{3}{*}{ p-value } \\
\hline & \multicolumn{2}{|c|}{ Konstruktif } & \multicolumn{2}{|c|}{ Destruktif } & & & & \\
\hline \multirow{3}{*}{ Laki-laki } & $\mathrm{n}$ & $\%$ & $\mathrm{~N}$ & $\%$ & $\mathrm{n}$ & $\%$ & & \\
\hline & 160 & $64 \%$ & 90 & $36 \%$ & 250 & $100 \%$ & 2,25 & \multirow{3}{*}{0,345} \\
\hline & & & & & & & 0,626 & \\
\hline \multirow{2}{*}{ Perempuan } & 200 & $80 \%$ & 50 & $20 \%$ & 250 & $100 \%$ & 8,057 & \\
\hline & 360 & $72 \%$ & 140 & $28 \%$ & 500 & $100 \%$ & & \\
\hline
\end{tabular}

Hasil analisa diperoleh mekanisme koping laki-laki sebanyak 160 orang (64\%) konstruktif dan 90 orang (36\%) memiliki mekanisme koping destruktif, sedangkan mekanisme koping perempuan diperoleh 200 orang $(80 \%)$ konstruktif dan 50 orang $(20 \%)$ destruktif.

Uji Chi Square perbedaan mekanisme koping antara mahasiswa laki-laki dan perempuan dalam menghadapi ujian semester ganjil tahun ajaran 2010/2011 di Fakultas Tarbiyah IAIN Raden Intan Lampung menghasilkan nilai Chi Square $\left(\chi^{2}\right)$ sebesar 0,893 dan 2 tabel sebesar 3,488. Dari hasil analisa diperoleh pula nilai $\mathrm{OR}=2,250$ (95\% CI : 0,628-8,057), artinya mahasiswa laki-laki mempunyai peluang 2,25 kali mempunyai mekanisme koping desruktif dibanding mahasiswa perempuan.

Berdasarkan hasil analisa diatas maka Hipotesis yang menyatakan "Ada perbedaan mekanisme koping antara mahasiswa laki- laki dan perempuan dalam menghadapi ujian semester ganjil tahun ajaran 2010/2011 di Fakultas Tarbiyah IAIN Raden Intan Lampung" ditolak, karena nilai $\chi^{2}$ hitung $<\chi^{2}$ tabel.

Dari penelitian yang dilakukan pada 500 responden mahasiswa Fakultas Tarbiyah IAIN Raden Intan Lampung (250 mahasiswa laki-laki dan 250 mahasiswa perempuan), yang dilakukan dari tanggal 12 s.d 28 Desember 2011 diperoleh hasil 160 orang (64\%) mahasiswa laki-laki memiliki mekanisme koping konstruktif dan 90 orang (36\%) memiliki mekanisme koping destruktif. Sedangkan mekanisme koping perempuan diperoleh 200 orang $(80 \%)$ memiliki mekanisme koping konstruktif dan 50 orang (20\%) memiliki mekanisme koping destruktif.

Dari hasil data diatas diperoleh yaitu mekanisme koping konstruktif perempuan sebesar $80 \%$ dan mekanisme koping konstruktif laki-laki sebesar 64\%, hal ini menunjukkan bahwa 
mekanisme koping mahasiswa perempuan di Fakultas Tarbiyah IAIN Raden Intan Lampung lebih konstruktif dibandingkan dengan mekanisme koping mahasiswa laki-laki.

Data yang diperoleh kemudian dihitung dengan menggunakan metode Chi Square sehingga didapat hasil $\chi^{2}$ hitung lebih kecil dari $\chi^{2}$ tabel. Hal ini dapat menjawab rumusan masalah penelitian mengenai perbedaan mekanisme koping mahasiswa laki-laki dan perempuan dalam menghadapi ujian semester ganjil tahun ajaran 2010/2011 di Fakultas Tarbiyah IAIN Raden Intan Lampung yaitu "tidak ada perbedaan mekanisme koping antara mahasiswa laki- laki dan perempuan dalam menghadapi ujian semester ganjil tahun ajaran 2010/2011 di Fakultas Tarbiyah IAIN Raden Intan Lampung”.

Bila dibandingkan dengan teori, hasil penelitian diatas terdapat perbedaan. Menurut (Elizabeth, 1999), perbedaan mekanisme koping yang digunakan pada laki-laki dengan perempuan disebabkan oleh faktor fisiologi, dimana kecenderungan perempuan lebih menggunakan mekanisme koping yang berfokus pada emosi sedangkan laki-laki menggunakan mekanisme koping fokus problem. Pada mekanisme koping yang berfokus pada problem akan menghasilkan mekanisme koping konstruktif dan mekanisme koping yang berfokus pada emosi akan menghasilkan mekanisme koping yang destruktif, karena akan mengedepankan perasaan dari pada pemecahan masalah. Menurut pendapat Weiten dalam (Yusuf, 2004), koping konstruktif memiliki ciri sebagai berikut: menghadapi masalah secara langsung, mengevalusi alternatif secara rasional dalam upaya memecahkan masalah, menilai atau mempersepsikan situasi stress didasarkan kepada pertimbangan yang rasional, mengendalikan diri (self control) dalam mengatasi masalah yang dihadapi.

Mekanisme koping destruktif seperti melarikan diri dari kenyataan atau situasi stress yang bentuknya seperti sikap apatis, kehilangan semangat atau perasaan tidak berdaya, minumminuman keras atau mengkonsumsi obat-obatan terlarang, mencela diri sendiri atau menilai negatif diri sendiri, agresif yaitu berbagai prilaku yang ditujukan untuk menyakiti orang lain, memanjakan diri sendiri dengan prilaku berlebihan seperti makan yang enak- enak, merokok, minum-minuman keras, menghabiskan uang untuk berbelanja, serta mekanisme pertahanan diri yang bentuknya seperti menolak kenyataan dengan cara melindungi diri dari suatu kenyataan yang tidak menyenangkan dengan cara seperti seorang perokok mengatakan bahwa rokok merusak kesehatan hanya teori belaka, berfantasi, intelektualisasi.

Berdasarkan pendapat ahli diatas ada perbedaan mekanisme koping antara laki-laki dan perempuan. Dari hasil penelitian yang dilakukan peneliti diperoleh hasil yaitu tidak ada perbedaan mekanisme koping antara laki-laki dan perempuan, hal ini kemungkinan terjadi karena pengaruh beberapa faktor yaitu : pertama semakin maju dan berkembangnya zaman, maka pola pikir perempuan semakin maju pula dimana bila mereka mempunyai masalah dari pada duduk melamun dan menangis lebih baik mencari alternatif penyelesaian masalah, kedua stress yang dialami responden dalam menghadapi ujian tengah semester memacu mahasiswa untuk mendapatkan prestasi belajar yang tinggi, ketiga kuesioner kurang banyak sehingga kurang menggali mekanisme koping responden, keempat jawaban responden terbagi 4 sehingga responden cenderung memilih menjawab dengan nilai tinggi, kelima waktu dan tempat kurang tepat, dimana kuesioner dibagikan saat akan menghadapi ujian tengah semester dan diisi diluar ruangan sehingga responden kurang konsentrasi dalam menjawab pertanyaan, keenam sampel penelitian kurang banyak sehingga jawaban kurang mewakili.

\section{Simpulan dan Saran}

Berdasarkan pembahasan pada Bab IV, maka kesimpulan dari penelitian ini adalah:

1. Pada variabel mahasiswa laki-laki diperoleh sebanyak 160 responden $(64 \%)$ mempunyai mekanisme koping konstruktif dan sebanyak 90 responden (36\%) mempunyai mekanisme koping destruktif. 
2. Pada variabel perempuan diperoleh sebanyak 200 responden $(80 \%)$ mempunyai mekanisme koping konstruktif dan sebanyak 50 responden $(20 \%)$ memiliki mekanisme koping destruktif.

3. Hasil analisis Bivariat menggunakan Chi Square diperoleh $\chi^{2}$ hitung $=0,893$ dan $\chi^{2}$ tabel $=3,488$. Hal ini berarti tidak ada perbedaan mekanisme koping antara mahasiswa lakilaki dan perempuan dalam menghadapi ujian semester ganjil tahun ajaran 2010/2011 di Fakultas Tarbiyah IAIN Raden Intan Lampung.

\section{Daftar Pustaka}

Berpusat pada Hati. Jakarta: Al- Mawardi. Elizabeth, W. (1999). Coping with Sress. Retrieved from Coping with Sress: http//:www.Psycologi.Com

Ginanjar, G. A. (2007). Rahasia Sukses Membangun Kecerdasan Emosi dan Spiritual: ESQ. Jakarta: Arga.

Kozier. (1999). Fundamental of Nursing Concepts Procces and Practice. AddisonWesley Publishing Company Inc.

Lengua, J., \& Stomrmshak. (2000). Gender Roles and Personality. Retrieved from Gender: $\mathrm{http} / /$ :www.findarticle.com

Lickona, T. (1992). Educating for Character, How Our Schools Can Teach Respect and Responsibility. New York: Bantam Books.

Lickona, T. S. (2003). CEP's Eleven Principles of Effective Character Education. Washington, DC: Character Education Partnership.

Niven, N. (2000). Psikologi Kesehatan Pengantar untuk Perawat dan Profesi Kesehatan lain. Jakarta: EGC.

Philips, S. U. (2001). Participant structures and communicative competence: Warm Springs children in community and classroom.

Smet, B. (1994). Psikologi Kesehatan. Jakarta: Grasindo.

Stuart, G., \& Laraia, M. (1998). Principles and Practices of Psyciatric Nursing. St Lois: Mosby Inc.

Taylor, C. L., \& C. Le Mone.P. (1997). Fundamental of Nursing Care. Lippincott: Raven Publishers.

Yusuf, S. (2004). Mental Hygiene Pengembangan Kesehatan Mental dalam Kajian Psikologi dan Agama,. Jakarta: Pustaka Bani Quraisy 